At-Turats

Jurnal Pemikiran Pendidikan Islam

journal homepage: http:/jurnaliainpontianak.or.id/index.php/atturats

\title{
WAJAH BURAM MADRASAH INDONESIA (STUDI PADA BEBERAPA MADRASAH TIDAK TERAKREDITASI DI PEDALAMAN KUBU RAYA)
}

\author{
Nur Hamzah \\ Fakultas Tarbiyah dan Ilmu Keguruan (FTIK) \\ Institut Agama Islam Negeri (IAIN) Pontianak \\ e-mail : hamzah_ptk@yahoo.com
}

\begin{abstract}
A B S T R A K
Membincang tentang pendidikan Indonesia, tidak bisa kita melepaskannya dengan Madrasah sebagai lembaga pendidikan Islam. Banyak konstribusi yang telah diberikan madrasah sebagai penyelenggara pendidikan di negeri ini. Ukuran konstribusi itu salah satunya adalah bahwa madrasah ikut memperluas akses kesempatan mengenyam pendidikan bagi anak usia sekolah. Hal itu sangat memungkinkan karena keberadaan madrasah yang sebagian besar ada di pelosok, pedalaman atau pinggiran daerah. Namun untuk melihat madrasah, kita perlu objektif karena tidak semua madrasah melaksanakan budaya mutu. Dalam riset yang peneliti lakukan pada tahun 2016, di Kubu Raya masih terdapat 66 madrasah dari semua tingkatan nilai akreditasinya $\mathrm{C}$ atau Tidak Terakreditasi (TT). Riset dilakukan pada 10 madrasah sampel mulai dari tingkat Ibtidaiyah, Tsanawiyah dan Aliyah. Penelitian ini dikhususkan pada untuk tiga standar pendidikan yakni standar Tenaga pendidik, proses dan sarana pra-sarana. Kesimpulannya bahwa madrasah belum memenuhi dan melaksanakan standar sebagaimana yang diatur oleh BSNP.
\end{abstract}

Kata Kunci: Akreditas Madrasah, Pendidikan, dan Pedalaman.

\section{LATAR BELAKANG}

Membincang tentang pendidikan Indonesia, tidak bisa kita melepaskannya dengan Madrasah sebagai lembaga pendidikan Islam. Banyak konstribusi yang telah diberikan madrasah sebagai penyelenggara pendidikan di negeri ini. Ukuran konstribusi itu salah satunya adalah bahwa madrasah ikut memperluas akses kesempatan mengenyam pendidikan bagi anak usia sekolah. Hal itu sangat memungkinkan karena keberadaan madrasah yang sebagian besar ada di pelosok, pedalaman atau pinggiran daerah.
Selain sebagai penyambung akses kesempatan memperoleh pendidikan, madrasah juga menjadi wadah untuk mentransformasikan pengetahuan dan nilai agama. Jika di sekolah umum pelajaran agama hanya mendapat porsi waktu 2 jam pelajaran, maka hal ini dirasakan sangat tidak memadai. Agama yang menurut hampir semua orang adalah pilar tak tergantikan dalam pembentukkan karakter menjadi sangat penting untuk ditransformasikan melalui lembaga pendidikan seperti sekolah. Terhadap kondisi inilah 
maka sebagian masyarakat yang memiliki komitmen dan kepedulian mendirikan wadah tempat anak-anak diberikan ilmu agama dan keterampilan keagamaan. Pada madrasah, mata pelajaran agama lebih banyak porsi waktunya. Pelajaran agama selanjutnya di pecah menjadi mata pelajaran Al-quran Hadist, Fiqh, Aqidah Akhlak dan Sejarah Islam. Terlebih lagi jika di madrasah aliyah jurusan agama, mata pelajaran agama menjadi lebih dispesfikkan seperti ada mata pelajaran Tarikh Tasyri', Ushul Fiqh, Ilmu Kalam dan lain sebagainya. Melalui lembaga pendidikan madrasah inilah diharapkan terjadi pewarisan keilmuan keagamaan Islam.

Berangkat dari cita-cita ideal di ataslah maka pendirian madrasah di negeri ini tidak hanya di inisiasi oleh pemerintah tetapi juga oleh perorangan atau sekelompok orang. Bahkan untuk kasus di Indonesia, bahwa lembaga pendidikan madrasah yang dikelola oleh yayasan swasta jumlahnya lebih banyak ketimbang madrasah yang dibawah naungan pemerintah (kementerian agama). Hal ini menunjukkan bahwa kebutuhan dan kepedulian terhadap madrasah sangat urgen. Ditengah lembaga pendidikan umum misalkan, madrasah masih mendapat eksistensi dan apresiasi bagi masyarakat dilokusnya. Masyarakat punya harapan bahwa madrasah akan memberikan tidak hanya sekedar pengetahuan yang dibutuhkan untuk berta-han dan bersaing hidup, tetapi juga dapat membekali anak mereka dengan suatu yang dapat menyelematkan kehidupan saat diakhirat kelak. Oleh sebab itu maka, madrasah di Indonesia ini akan tetap dapat survive juga eksist manakala masih banyak orang yang berpikir sedemikian.

Tetapi perkara membuat madrasah tetap survive dan eksist bukanlah perkara mudah dan hanya cukup sedemikian. Di antara madrasah, terdapat lembaga pendidikan lain yang dimana ia niscaya dapat bersaing atau paling tidak setara. Jika madrasah tidak dapat menunjukkan kelebihanya maka ia secara perlahan akan ditinggalkan. Pesona madrasah sebagai lembaga pendidikan yang memberikan nilai lebih akan menjadi pudar karena ia tidak dikelola secara baik atau menghasilkan out put berkualitas. Demikian faktanya bahwa diantara sejumlah madrasah yang berdiri, sebgian diantaranya dalam kondisi memprihatinkan bahkan hingga tutup. Ini maknanya bahwa madrasah sebagai sebuah lembaga pendidikan didirikan tidak hanya bisa dengan modal niat dan keingginan. Komitmen mendirikan madrasah niscaya berbarengan dengan ikhtiar keras juga cerdas yang sistematis, berkesinambungan dan terprogram.

Di Kalimantan Barat, jumlah madrasah mulai dari tingkat ibtidaiyah hingga Aliyah paling tidak sebanyak 315 buah, ini menunjukkan bahwa ghirah mendirikan madrasah sebagai pusat pendidikan Islam juga tinggi. Adapun sebarannya, yang paling banyak adalah di Kabupaten Kubu Raya. Di Kabupaten ini hampir tiap desa terdapat madrasah. Tetapi lagi-lagi kita tidak boleh berhenti dan gembira pada jumlah/kuantitas madrasah. Jika melihat lebih dalam kondisi riil madrasah, sebagian madrasah eksist dan dapat bersaing dengan lembaga pendidikan formal lain. Katakanlah jika di Kabupaten Kubu Raya terdapat Madrasah Tsanawiyah dan Aliyah Al-Mustaqiem di Sungai Raya, Madrasah Aliyah Darul Ulum di Kuala Dua, Madrasah Aliyah As-salam, Madrasah Ibtidaiyah Imanuddin Sungai Raya Dalam dan beberapa madrasah lainnya.

Sebagian lagi, madrasah di Kabupaten ini dalam kondisi memprihatinkan. Sebutlah diantaranya Madrasah Ibtidaiyah Darussuadah di Desa Tebang Kacang. Madrasah ini berdiri tahun 2005, tepatnya dilokasi eks pengungsian kerusuhan sosial Sambas. Dari hasil pengamatan yang ada, madrasah ini hanya memiliki 3 ruang belajar sementara rombongan belajar ada 6 . Sarana belajar seperti bangku dan meja tidak layak sebagai meja belajar karena meja yang digunakan adalah meja dan kursi panjang yang muat untuk 6-8 orang. Ruang belajar hanya berukuran $5 \times 5$ meter sementara ukuran ideal adalah 8x8 M2. 


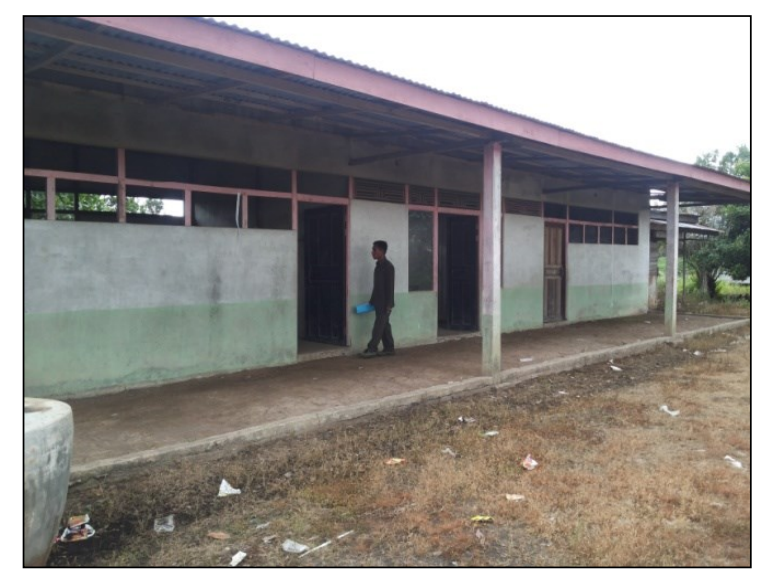

Gambar 1: Salah Satu Bentuk Fisik Bangunan Madrasah di Kubu Raya

Belum lagi fasilitas lain, bahwa madrasah ini tidak memiliki kantor dan ruang guru. Mensiasati hal ini kepala sekolah melakukan pengadministrasian pendidikan di rumahnya. Guru juga berkumpul di rumahnya saat selesai mengajar. Madrasah ini juga tidak memiliki koleksi perpusta-kaan untuk sumber belajar anak, tidak memiliki sarana media pembelajaran, tidak memiliki toilet dan lain sebagainya.

Belum lagi tentang tenaga pendidik. Tidak ada satupun baik kepala sekolah maupun guru yang lulusan strata satu. Paling tinggi adalah ada diantara guru yang sedang dalam penyelesaian S1, sementara yang lain tamatan SMA sederajat atau pesantren. Melihat kondisi sementara ini, maka wajar sebagaimana hasil wawancara awal peneliti kepada kepala madrasah, bahwa madrasah ini belum terakreditasi.

Tabel 1:

Data Madrasah dan Akreditasinya di Kubu Raya Tahun 2016

\begin{tabular}{|l|l|c|c|c|c|}
\hline No. & $\begin{array}{l}\text { Jen } \\
\text { jang }\end{array}$ & $\begin{array}{c}\text { Perin } \\
\text { gkat } \\
\text { A }\end{array}$ & $\begin{array}{c}\text { Perin } \\
\text { gkat } \\
\text { B }\end{array}$ & $\begin{array}{c}\text { Perin } \\
\text { gkat } \\
\text { C }\end{array}$ & $\begin{array}{c}\text { Perin } \\
\text { gkat } \\
\text { TT }\end{array}$ \\
\hline 1. & MI & 10 & 23 & 19 & 28 \\
\hline 2. & MTs & 0 & 6 & 12 & 6 \\
\hline 3. & MA & 1 & 3 & 1 & 0 \\
\hline & Jum & $\mathbf{1 1}$ & $\mathbf{3 8}$ & $\mathbf{3 2}$ & $\mathbf{3 4}$ \\
\hline
\end{tabular}

Sumber: data digital dari Kanwail.Kemenag Prop. Kal-Bar
Berdasarkan kajian teoritik dan hasil observasi awal diatas, maka penulis melakukan riset mini mengenai potret madrasah yang ada di daerah pinggirian Kubu Raya. Riset ini dilakukan khusus pada madrasah-madrasah tidak terakreditasi yang ada di pedalaman atau pinggiran Kab. Kubu Raya. Sebagai sample, terdapat 6 madrasah tingkat MI dan MTs yang dijadikan objek penelitian.

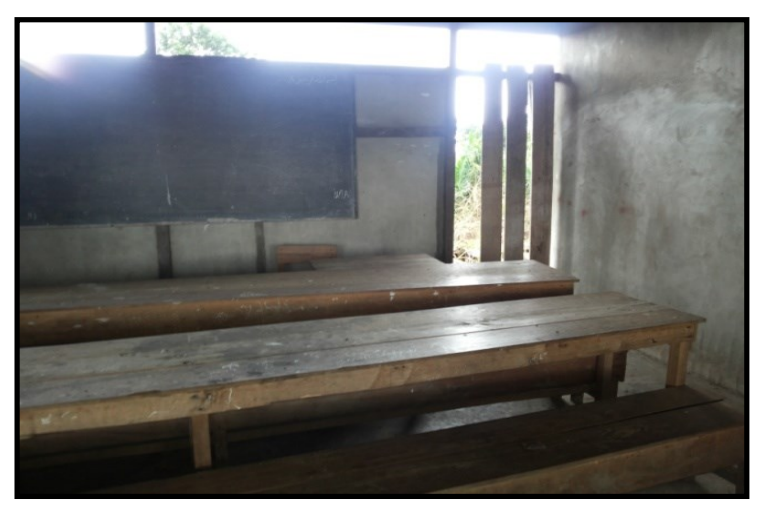

Gambar 2: Bentuk Fisik Bangunan Madrasah dari Dalam di Kubu Raya

\section{PENGERTIAN MADRASAH}

Kata madrasah berasal dari bahasa Arab. Secara harfiah, kata ini berarti dengan kata sekolah. Madrasah mengandung arti tempat, wadah anak menyenyam proses pembelajaran. Artinya pada ranah ini sebenarnya madrasah sama saja denga sekolah, yaitu sebagi tempat dimana proses atau kegiatan belajar mengajr dilaksanakan secara tersistem, terkendali, terprogram, berkelanjutan dan terarah. Lalu karena faktor sejarah dan budaya, madrasah kemudian diidentikkan dengan sekolah agama khususnya Agama Islam.

Kata madrasah, yang kemudian secara harfiah diidentikkan dengan sekolah agama, dalam perjalanannya telah mengalami metamorfosa. Metamorfosa terjadi pada kurikulum, sistem pembelajaran, struktur dan lain sebagainya. Hal ini wajar karena madrasah sangat lentur dengan asimilasi yang terjadi pada perubahan zaman, tempat dan budaya dimana ia berada. 
Sebagaimana sejarah, pada awalnya pendidikan melembaga pada pendidikan surau, masjid dan pesantren. Seiring perkembangan keilmuan maka dirasakan pendidikan di surau, masjid dan pesantren belum cukup mewadahi kelimuan yang berjalan sangat cepat terutama ilmu umum. oleh sebab itulah kemudian bagi beberapa cendikiawan muslim, memunculkan gagasan pendidikan madrasah sebagai transformasi kelembagaan pendidikan agama ke pendidikan modern. Dalam catatan sejarah, madrasah pertama kali berdiri di Sumatra, Madrasah Adabiyah (1908, dimotori Syekh Abdullah Ahmad), tahun 1910 berdiri Madrasah School di Batusangkar oleh Syaikh M. Taib Umar, kemudian M. Mahmud Yunus pada 1918 mendirikan Diniyah School sebagai lanjutan dari Madrasah School. Madrasah Tawalib didirikan Syeikh Abdul Karim Amrullah di Padang Panjang (1907). Lalu, Madrasah Nurul Uman dididirikan $H$. Abdul Somad di Jambi (Malik Fajar, 19,1998)

Madrasah berkembang di Jawa mulai 1912. Ada model madrasah-pesantren NU dalam bentuk Madrasah Awaliyah, Ibtidaiyah, Tsanawiyah, Muallimin Wustha, dan Muallimin Ulya (mulai 1919); ada madrasah yang mengapropriasi sistem pendidikan Belanda plus, seperti Muhammadiyah (1912) yang mendirikan Madrasah Ibtidaiyah, Tsnawiyah, Muallimin, Muballighin, dan madrasah Diniyah. Ada juga model Al-Irsyad (1913) yang mendirikan madrasah Awaliyah, Ibtidaiyah, Madrasah Tahjiziyah, Muallimin dan Tahassus; atau model madrasah PUI di Jabar yang mengembangkan madrasah pertanian.

\section{PROBLEMATIKA PENDIDIKAN DI MADRASAH}

Dalam peta pendidikan Indone-sia, madrasah adalah salah satu lembaga pendidikan terpenting. Dianggap terpenting karena madrasah merupakan jembatan penghubung antara pendidikan agama murni seperti pesantren, masjid dan surau dengan pendidikan umum modern seperti sekolah. Pada aspek pengembangan keilmuan, madrasah mengembangkan dan mengajarkan ilmu umum yang di sekolah sekaligus mengajarkan ilmu agama sebagaimana di pesantren. Dalam ranah metode dan sistem pengajaran juga demikian bahwa metode pelaksanaan pendidikan madrasah adalah inovasi dan pengembangan dari metode yang dilaksanakan di pesantren. Termasuk dalam hal ini adalah bahwa madrasah adalah lembaga pendidikan yang mewariskan keilmuan umum dan agama.

Tetapi fakta urgensitas di atas tidak sebagaimana nyatanya. Kondisi riil madrasah untuk mewujudkan sigifikansi kehadirannya dihadapkan pada fakta-fakta masalah. Di antara masalah yang dirasakan oleh madrasah secara umum misalnya:

1. Kondisi sarana dan pra-sarana pendukung PBM yang minim. Banyak madrasah yang didirikan awalnya tidak memiliki gedung sendiri melainkan menumpang. Kalau pun ada gedung yang mereka miliki kondisinya sangat memprihatinkan. Ruang kelas yang ada tidak sebagaimana yang telah terstandarkan oleh lembaga berwenang seperti BAN. Belum lagi jika melongok kondisi sarana lain misalnya kelengkapan referensi perpustakaan, peralatan laboratorium, alat peraga mata pelajaran dan lain sebagainya;

2. Keterbatasan sumber daya manusia. Sumber daya manusia ini adalah tenaga guru dan tenaga kependidikan. Masih banyak madrasah yang tenaga gurunya tamatan SMA sederajat atau pesantren yang seharusnya adalah minimal strata satu (S1). Belum lagi jika berbicara tentang kesesuaian latar belakang pendidikan dengan mata pelajaran yang diajar. Karena keterbatasan ini maka banyak guru yang mengajar tidak sesuai dengan bidangnya;

3. Keterbatasan sumber pendanaan. Sudah menjadi fakta bahwa jumlah madrasah di Indonesia ini sebagian besar dikelola oleh pihak swasta wa bil khusus 
yayasan. Yayasan terkadang hampir tidak memiliki sumber pembiayaan lain kecuali dari bantuan pemerintah dan dari siswa. Jika hanya mengandalkan dari dua sumber ini maka hampir dipastikan madrasah akan kekurangan dana operasional. Karena kekurangan sumber pembiayaan maka program pengembangan kependidikan menjadi tersendat. Biaya lebih banyak dialokasi pada unsur belanja pegawai;

4. Kebijakan pemerintah yang masih setengah hati. Sebagaimana diketahui bahwa baru beberapa dekade belakangan saja madrasah statusnya disamakan. Disamakan artinya statusnya sama dengan sekolah, out put madrasah sama dengan out put sekolah. Tetapi itu saja sebenarnya tidak cukup, jika dilihat kebijakan penganggaran maka nampak ketimpangannya. Termasuk dalam hal ini adalah kebijakan pengangkatan guru, kebijakan tata kelola dan lain sebagainya.

5. Sebagian besar madrasah di Indonesia dikelola oleh stake holder yang tak berkompeten. Stake holder tersebut misalnya ketua yayasan, kepala sekolah, kepala TU termasuk komite. Ketua yayasan kadang yang diangkat adalah orang yang meiliki lembaga tersebut atau orang yang dituakan tanpa skill dan konsep pendidikan. Kepala sekolah juga kadang demikian, adalah orang yang diangkat oleh yayasan yang dianggap dapat bekerjasama dengan yayasan, oleh sebab itu mengabaikan kemampuan leader ship, managemen dan pengembangan kelembagaan pendidikan.

6. Masalah berikutnya adalah kesiapan madrasah dalam menghadapi tuntutan globalisasi. Jika mau jujur termasuk out put madrasah, masih lemah dalam adaptasinya terhadap tuntutan globalisasi. Globalisasi menghendaki lulusan yang siap di dunia kerja,
Melihat sekilas didentfikasi problematika dan kelemahan madrasah tersebut, dalam rangka tetap dapat survive dan eksistens, niscaya madrasah melakukan beragam ikhtiar percepatan pengembangan lembaga. Termasuk dalam hal ini adalah upaya pemerintah selaku pemangku tertinggi kebijakan pendidikan di negara.

\section{POTRET MADRASAH TIDAK TERKAREDITASI}

Dalam mengukur tingkat kualitas pelaksanaan pendidikan, di Indonesia dibuat sebuah standar yang namanya Standar Nasional Pendidikan. Standar nasional pendidikan merupakan kriteria minimal tentang sistem pendidikan di seluruh wilayah hukum Negara Kesatuan Republik Indonesia. Standar Nasional Pendidikan itu sendiri terdiri dari 8 poin yang harus dimiliki dan dipenuhi oleh penyelenggara dan/atau satuan pendidikan yang ada di Indonesia yakni: Standar Kompetensi Lulusan, Standar Isi, Standar Proses, Standar Pendidikan dan Tenaga Kependidikan, Standar Sarana dan Prasarana, Standar Pengelolaan, Standar Pembiayaan Pendidikan, dan Standar Penilaian Pendidikan.

Dalam hal memotret seperti apa deskripsi madrasah yang tidak terakreditasi di Kubu Raya, maka standar nasional pendidikan dapat kita gunakan sebagai pisau analisa. Dalam tulisan ini, penulis hanya memaparkan kondisi madrasah berdasarkan 3 standar yakni standar sarana dan prasarana, standar tenaga pendidik dan stardar isi atau proses belajar mengajarnya.

\section{KONDISI SARANA DAN PRASARANA}

Dalam peta pendidikan Indonesia, madrasah adalah salah satu lembaga pendidikan terpenting. Dianggap terpenting karena madrasah merupakan jembatan penghubung antara pendidikan agama murni seperti pesantren, masjid dan surau dengan pendidikan umum modern seperti 
sekolah. Pada aspek pengembangan keilmuan, madrasah mengembangkan dan mengajarkan ilmu umum yang di sekolah sekaligus mengajarkan ilmu agama sebagaimana di pesantren. Dalam ranah metode dan sistem pengajaran juga demikian bahwa metode pelaksanaan pendidikan madrasah adalah inovasi dan pengembangan dari metode yang dilaksanakan di pesantren. Termasuk dalam hal ini adalah bahwa madrasah adalah lembaga pendidikan yang mewariskan keilmuan umum dan agama.

Tetapi fakta urgensitas di atas tidak sebagaimana nyatanya. Kondisi riil madrasah untuk mewujudkan sigifikansi kehadirannya dihadapkan pada fakta-fakta masalah. Di antara masalah yang dirasakan oleh madrasah adalah kondisi sarana dan pra-sarana pendukung PBM yang minim. Banyak madrasah yang didirikan awalnya tidak memiliki gedung sendiri melainkan menumpang. Kalau pun ada gedung yang mereka miliki kondisinya sangat memprihatinkan. Ruang kelas yang ada tidak sebagaimana yang telah terstandarkan oleh lembaga berwenang seperti BAN. Belum lagi jika melongok kondisi sarana lain misalnya kelengkapan referensi perpustakaan, peralatan laboratorium, alat peraga mata pelajaran dan lain sebagainya.

Jika melihat data hasil observasi dan wawancara tentang sarana dan pra-sarana yang dimiliki oleh madrasah pedalaman di Kubu Raya sepertinya mengalami hal serupa. Bahwa madrasah sangat minim dengan sarana dan pra-sarana pendidikan. Untuk ruang belajar misalnya, ada madrasah yang menyekat ruangnnya menjadi dua kelas tanpa sekat permanen. Hal ini tentu saja akan menimbulkan kondisi ketidaknyamanan baik guru ataupun siswa saat melakukan pembelajaran. Konsentrasi tentunya tidak akan full terpusat pada pembelajaran di kelas melainkan akan ke kelas sebelahnya juga. Akan ada polusi suara juga yang terjadi yang asal atau sumbernya dari kelas sebelah dan sederet masalah lainnya yang akan timbul.
Berdasarkan fakta juga bahwa banyak madrasah yang minim akan sarana seperti sumber belajar berupa buku paket, koleksi buku perpustakaan dan termasuk media pembelajaran. Padahal dalam kajian teoritik bahwa sarana pokok dimaksud adalah kebutuhan wajib yang harus terpenuhi. Demikian pula menurut peraturan pemerintah tentang standar saranaprasarana pendidikan sebagaimana pada Pasal 42 ayat (1): Setiap Satuan pendidikan wajib memiliki sarana yang meliputi perabot, peralatan pendidikan, media pendidikan, buku dan sumber belajar lainnya, bahan habis pakai, serta perlengkapan lain yang diperlukan untuk menunjang proses pembelajaran yang teratur dan berkelanjutan.

Pasal 42 ayat (2): Setiap satuan pendidikan wajib memiliki prasarana yang meliputi lahan, ruang kelas, ruang pimpinan satuan pendidikan, ruang pendidik, ruang tata usaha, ruang perpustakaan, ruang laboratorium, ruang bengkel kerja, ruang unit produksi, ruang kantin, instalasi daya dan jasa, tempat berolah raga, tempat beribadah, tempat bermain, tempat berkreasi, dan ruang/tempat lain yang diperlukan untuk menunjang proses pembelajaran yang teratur dan berkelanjutan.

Berdasarkan kajian diatas maka dapat disimpulkan bahwa sarana dan pra-sarana yang dimiliki oleh madrasah-madrasah pedalaman di Kubu Raya belum terstandar dan memenuhi persyaratan sebagaimana yang diatur BSNP.

\section{KONDISI TENAGA PENDIDIK}

Masalah berikutnya selain sarana dan pra-sarana adalah keterbatasan sumber daya manusia. Sumber daya manusia ini adalah tenaga guru dan tenaga kependidikan. Masih banyak madrasah yang tenaga gurunya tamatan SMA sederajat atau pesantren yang seharusnya adalah minimal starata satu (S1). Belum lagi jika berbicara tentang kesesuaian latar belakang pendidikan dengan mata pelajaran yang diajar. Karena keterbatasan ini maka banyak guru 
yang mengajar tidak sesuai dengan bidangnya.

Mengajar adalah satu pekerjaan profesional yang menuntut kemampuan yang kompleks untuk dapat melakukannya. Sebagaimana halnya pekerjaan profesional yang lain, pekerjaan seorang guru menuntut keahlian tersendiri sehingga tidak setiap orang mampu melakukan pekerjaan tersebut sebagaimana mestinya. Ada seperangkat kemampuan yang harus dimiliki oleh seorang guru. Perangkat kemampuan tersebut disebut kompetensi guru. Menurut Peraturan Pemerintah Nomor 19 Tahun 2005 Tentang Standar Nasional Pendidikan, seorang guru dituntut untuk menguasai kompetensi pedagogis, profesional, kepribadian, dan sosial.

Kompetensi pedagogis berkenaan dengan kemampuan mengelola pembelajaran dalam rangka mengaktualisasikan berbagai kompetensi yang dmiliki peserta didik. Salah satu kemampuan yang dituntut dari kompetensi ini adalah kemampuan melaksanakan pembelajaran yang mendidik. Agar dapat melaksanakan pembelajaran yang mendidik dengan baik, di samping menguasai berbagai kemampuan, guru dipersyaratkan untuk menguasai keterampilan dasar mengajar, yang merupakan salah satu aspek penting dalam kompetensi guru.

Berdasarkan kajian ini maka dapat disimpulkan bahwa sebagian guru yang mengajar di madrasah pedalaman Kubu Raya belum sepenuhnya kompeten. Hal ini ditan-dai dengan masih banyak guru tamatan SMA sederajat atau kalapun ada guru dengan kualifiksi S1 tetapi guru tersebut bukan dari fakultas kependidikan. Berikut contoh data kualifikasi pendidikan guru:

Data MTs. Nurul Islam jumlah 3 Rombel :

\begin{tabular}{|c|c|c|c|c|c|}
\hline \multicolumn{4}{|c|}{ Jenjang Pendidikan } & \multicolumn{2}{c|}{$\begin{array}{c}\text { Kesesuaian } \\
\text { Bidang }\end{array}$} \\
\hline SMA & D2/D3 & S1 & S2 & Sesuai & $\begin{array}{c}\text { Tdk. } \\
\text { S }\end{array}$ \\
\hline 9 & - & 2 & - & 2 & 9 \\
\hline
\end{tabular}

Sebagaimana PP. nomor 19 tahun 2005 tentang standar nasional pendidikan pasal 28 ayat (1) menyebutkan bahwa Pendidik harus memiliki kualifikasi akademik dan kompetensi sebagai agen pembelajaran, sehat jasmani dan rohani, serta memiliki kemampuan untuk mewujudkan tujuan pendidikan nasional. Pasal 29: Kualifikasi pendidik usia dini dan dikdasmen minimum diploma empat (D IV) atau Sarjana (S1). Jika mengacu kepada hal ini maka aspek tenaga pendidik belum memenuhi syarat dan wajar jika dilakukan akreditasi maka mendapat hasil $\mathrm{C}$ atau TT.

\section{KEGIATAN PROSES BELAJAR MENGAJAR (PBM)}

Kegiatan pembelajaran dalam standar nasional pendidikan masuk pada standar standar proses. Proses pembelajaran pada satuan pendidikan diselenggarakan secara interaktif, inspiratif, menyenangkan, menantang, memotivasi peserta didik untuk berpartisipasi aktif, serta memberikan ruang yang cukup bagi prakarsa, kreativitas, dan kemandirian sesuai dengan bakat, minat, dan perkembangan fisik serta psikologis peserta didik. Selain itu, dalam proses pembelajaran pendidik memberikan keteladanan. Setiap satuan pendidikan melakukan perencanaan proses pembelajaran, pelaksanaan proses pembelajaran, penilaian hasil pembelajaran, dan pengawasan proses pembelajaran untuk terlaksananya proses pembelajaran yang efektif dan efisien.

Berdasarkan data lapangan bahwa proses pembelajaran pada madrasah pedalaman Kubu Raya belum memenuhi standar BSNP. Perencanaan pembelajaran tidak dilakukan oleh para guru dalam hal ini adalah tidak membuat silbus dan RPP. Guru tidak memiliki pengetahuan dalam merancang RPP menggunakan acuan kurikulum 2013. Wal hasil pembelajaran dilakukan tanpa pembelajaran.

Kualitas peserta didik ditentukan oleh kualitas kegiatan pembelajaran. Peningkatan kualitas kegiatan pembelajaran disekolah merupakan kebutuhan yang mutlak yang sangat mendesak. Salah satu 
upaya untuk meningkatkan kualitas kegiatan pembelajaran adalah dengan meningkatkan proses pelaksanaan pembelajaran disekolah yang baik. Pembelajaran adalah proses interaksi peserta didik dengan guru dan sumber belajar pada suatu lingkungan belajar. Proses pembelajaran perlu direncanakan, dilaksanakan, dinilai dan diawasi agar terlaksana secara efektif dan efisien.

\section{KESIMPULAN}

Berdasarkan data yang diperoleh hasil riset ini maka dapat disimpulkan secara umum bahwa terdapat beberapa madrasah tidak terakreditasi di pedalaman Kubu Raya yang belum menjalankan kegiatan pendidikan sesuai dengan standar pendidikan sebagaimana yang diatur dalam SNP. Secara khusus hal ini ini dapat dijabarkan sebagai berikut:

1. Bahwa keadaan atau kondisi sarana dan pra-sarana yang dimiliki sebagian madrasah tidak terkareditasi di Kubu Raya masih belum lengkap dan tidak terstandar. Sarana pokok seperti sumber belajar, media pembelajaran, koleksi perpustakaan dan pra-sarana seperti ruang belajar, ruang kantor, ruang laboratorium serta lainnya lagi tidak lengkap dan belum memadai.

2. Bahwa keadaan atau kondisi tenaga pendidik yang mengajar di sebagian madrasah tidak terakreditasi di pedalaman Kubu Raya juga masih belum sesuai kriteria SNP. Masih banyak guru dengan kualifikasi pendidikan di bawah S1 dan mengajar tidak sesuai bidang;

3. Bahwa kegiatan pembelajaran yang dilaksanakan di sebagian madrasah tidak terakreditasi di pedalaman Kubu Raya juga masih jauh dari kata layak atau berkualitas. Diantara indikatornya adalah guru tidak melakukan perencanaan pembelajaran, penggunaan metode secara monoton atau tidak variatif dan belum melakukan kegiatan penilaian pembelajaran secara prosedural.

\section{SARAN}

1. Disarankan kepada Kementerian Agama untuk membina secara intens madrasah yang tidak terakreditasi;

2. Perlu ada upaya sistematis dan terus menerus guna percepatan pelaksanaan pendidkan berkualitas sesuai dengan SNP;

3. Perlu ada politik anggaran agar masalah pembiayaan kegiatan pendidikan dapat teratasi, dengan demikian masalahmasalah lain yang ditimbulkan akibat kekurangan dana dapat terpecahkan.

\section{DAFTAR PUSTAKA}

Malik Fajar, Madrasah dan Tantangan Modernitas, Bandung, Mizan, 1998

HS, Mastuki, Asal Usul Madrasah, Artikel dari data internet dalam www. Bagais.co.id

Muhaimin, Pengembangan Kurikulum Pendidikan Agama Islam, PT. Raja Grafindo Persada, Jakarta, 2006.

Hasbullah, Sejarah Pendidikan Islam di Indonesia: Lintasan Sejarah

Pertumbuhan dan Perkembangan, Jakarta: PT RajaGrafindo Persada, 2001

Abdul Rchman Shaleh, Madrasah dan Pendidikan Anak Bangsa: Visi, Misi dan

Aksi, Jakarta: PT RajaGrafindo Persada, 2006

Maskuri Badillah, Pesantren Dalam Konteks Pendidikan Nasional dan Pengembangan Masyarakat, (dalam Pendidikan untuk masyarakat Indonesia baru), Ikhwanuddin dan Dodo Murtadlo (editor), Jakarta, PT Grasindo, 2002

Harun Rasyid, Metode Penelitian Kualitatif Bidang Sosial dan Agama, Pontianak: STAIN Press, 2000 